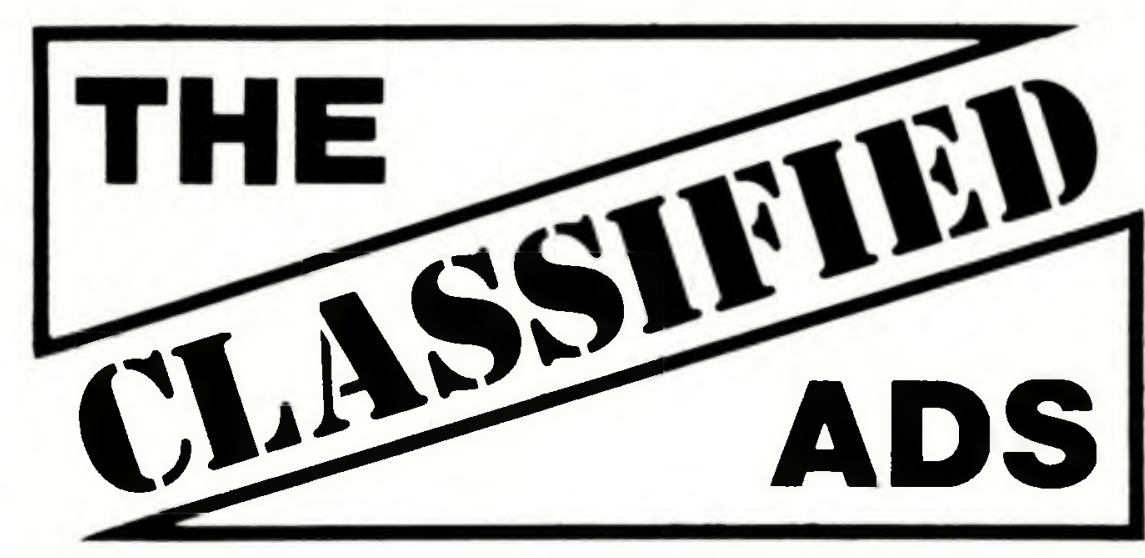

Deadlines: Orders for regular classified advertisements must reach the ACRL office on or before the second of the month preced ing publication of the issue (e.g. September 2 for the October issue) Late job listings will be accepted on a space-available basis after the second of the month.

Rates: Classified advertisements are $\$ 4.00$ per line for ACRL members, $\$ 5.00$ for others. Late job notices are $\$ 10.00$ per line for members, $\$ 12.00$ for others. Organizations submitting ads will be charged according to their membership status.

Telephone: All telephone orders should be confirmed by a written order mailed to ACRL headquarters as soon as possible. Orders should be accompanied by a typewritten copy of the ad to be used in proofreading. An additional $\$ 10$ will be charged for ads taken over ihe phone (except late job notices or display ads).

Guidelines: For ads which list an application deadline, that date must be no sooner than the last day of the month in which the notice appears (e.g., October 31 for the October issue). All job announce ments should include a salary figure. Job announcements will be edited to exclude discriminatory references. Applicants should be aware that the terms faculty rank and status vary in meaning among institutions.

JOBLINE: Call (312) 944-6795 for late-breaking job ads for academic and research library positions. A pre-recorded summary of positions listed with the service is revised weekly; each Friday a new tape includes all ads received by 1:00 p.m. the previous day. Each listing submitted will be carried on the recording for two weeks. The charge for each two-week listing is $\$ 30$ for ACRL members and $\$ 35$ for non-members.

Fast Job Listing Service: A special newsletter for those actively seeking positions. This service lists job postings received at ACRL headquarters four weeks before they appear in C\&RL News, as well as ads which, because of narrow deadlines, will not appear in C\&RL News. The cost of a six-month subscription is $\$ 10$ for ACRL members and $\$ 15$ for non-members.

Contact: Classified Advertising Dep't, ACRL, American Library Association, 50 E. Huron St., Chicago, IL 60611; (312) 944-6780.

\section{FOR SALE}

ELSEVIER ANTIQUARIAN DEPARTMENT. Periodicals and rare books on Life- and Earth Sciences. Over 1 million volumes on stock. Catalogues available on demand. Please write to: Lippijnstraat 4, $1055 \mathrm{KJ}$ Amsterdam, The Netherlands.

\section{POSITIONS OPEN}

ACQUISITIONS LIBRARIAN, Harvard Law School Library. As assistant head of the Collection Development Dept., plans, organizes and directs the operations of the acquisitions unit which includes searching, ordering, receiving, serial records, documents, gifts and exchanges and fiscal functions. Supervises 2 professionals, 11 support staff and casual assistants. Under the general supervision of the Assistant Librarian for Collection Development (dept. head), participates in developing and implementing policies and procedures for the acquiring and processing of library materials; works with selectors, reference/bibliographers, faculty and others in selection and acquisition of materials. Monitors $\$ 800,000$ materials budget Responsible for implementing Harvard's new automated acquisitions system. Harvard Law Library has a staff of 80 , a 1.4 million volume research collection, extensive special collections and is a special member of the Research Libraries Group. Qualifications: ALA accredited MLS, supervisory ability demonstrated by relevant experience, and substantial knowledge of acquisitions in an automated environment acquired through 3-5 years experience in a large research library are required. Significant experience with serials knowledge of automated library systems, ability to work with a wide variety of languages and familiarity with legal materials preferred. Effective communication skills and evidence of professional creativity and initiative expected. Rank: Librarian II; salary range:
$\$ 19,950-\$ 29,610$. Generous benefits. Position available January 1984. Send letter of application, resume and names of three references before Sept. 30th to: Barbara Lianides-Chin, Personnel Office Harvard Law Library, Langdell Hall, Cambridge, MA 02138.

ARCHIVIST. Richard B. Russell Memorial Library, University of Georgia Libraries (Salary minimum $\$ 14,800$ ). The Russell Library, a department of the Special Collections Division, functions as a center for the study of recent Georgia politics and houses the papers of U.S Senator Richard B. Russell and other 20th century U.S. Congressmen, state officials, and political figures. The staff of four acquire, preserve, and process permanent historical records according to archival procedures and standards and provide reference assistance to patrons. The Archivist reports to the Head of the Russell Library. Qualifications: ALA-accredited MLS; formal archival training or considerable professional experience in an archival setting; advanced degree in history or political science; effective communication skills; ability to establish and maintain effective working relationships with co-workers, donors, and patrons; interest in computer applications for archival collections. Application procedure: Send letter of application, resume and names of three references by October 14, 1983 to: Bonnie Jackson Clemens, Assistant Director for Administrative Services, University of Georgia Libraries, Athens, GA 30602 . This position will be filled only if suitable applicants are found. An equal opportunity, affirmative action institution.

ASSISTANT DIRECTOR. To assume responsibility for administrative services, special projects, and one department of a library serving 13,000 students and 700 faculty members. Library staffing includes 22 faculty, and 54 support staff positions. East Carolina is part of a 16-campus University of North Carolina system Minimum qual fications: ALA-accredited master's degree; four years of professional experience that reflects increasing supervisory responsibility in a library of comparable size and complexity or other evidence of interest in administrative work; evidence of involvement in professional association activities on the state, regional or national leve and experience in research and/or creative activity. Preferred: second graduate degree. Twelve-months appointment. Faculty rank

\section{$\longrightarrow$ \\ AFRO-AMERICAN SPECIALIST \\ Library of Congress}

Specialist in Afro-American history and culture, GS-13 (\$34,390-\$45,406 a year). The Library of Congress, Manuscript Division, Washington, D.C As senior specialist in Afro-American history and culture, recommends manuscript acquistions, negotiates with potential donors, represents the Library officially in professional associations and scholarly enterprises, conducts research and prepares articles on the manuscript collections for publication, and assists scholars and researchers in the field.

In addition to a master's in library science, American studies, or American history with concentration in Afro-American history and culture, or equivalent experience, position requires one year of specialized library or research work in a field beyond graduate study. To obtain a copy of Vacancy Announcement 30406 and application form (SF-171) write:

\section{Library of Congress \\ Recruitment and Placement Office Washington, DC 20540 (202) 287-5627}

The application form (SF-171) must refer to Announcement 30406, include a list of relevant courses, and be received in the Recruitment and Placement Office not later than September 30, 1983

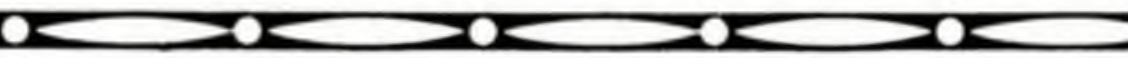


and fringe benefits. Minimum salary $\$ 22,000$. Send letters of application with resume and names of three references to: Ruth $M$. Katz, Joyner Library East Carolina University Greenville NC 27834. Applications must be postmarked on or before October 15, 1983. East Carolina University is an equal opportunity, affirmative action employer

ASSISTANT HEAD, REFERENCE/BIBLIOGRAPHIC SERVICES, AND BIBLIOGRAPHER FOR SOCIAL SCIENCES INCLUDING AFRO-AMERICAN STUDIES, Central Library, University of Cincinnati. Assists the Head of Reference/Bibliographic Services in the management of the Department and is responsible for building library collection in subject specialties and maintaining liaison with faculty in appropriate departments and for reference as-

(1)

\section{CHIEF LIBRARIAN City University of New York} (Search reopened)

Herbert H. Lehman College invites applications and nominations for a major appointment as Chief Librarian in the rank of Professor. Responsibilities: The Chief Librarian reports directly to the Provost and is responsible for all library operations including long-range plannning, budget preparation and administration, innovations in service, policy development, and cooperative efforts with other research libraries.

Qualifications: master's degree from an ALAaccredited library school and a doctorate or a second master's degree in another discipline; strong administrative experience and academic orientation; skills in management and personnel supervision; knowledge of library automation; and record of professional participation and, preferably, publication.

Salary: up to $\$ 50,144$ dependent upon qualifications; generous fringe benefits. Lehman College is a senior college of The City University of New York situated on a 37-acre, tree-lined campus on the Bronx-Westchester border. Its campus features Gothic-style buildings, Marcel Breuer architecture, a $\$ 50$ million Center for the Performing Arts, and a new library opened in 1980. More than 9,000 students from every borough of New York City, Westchester, and Long Island attend Lehman. The College. offers 74 undergraduate areas of specialization, 28 programs leading to the master's degree, and through the Graduate Center a doctoral program in plant sciences in conjunction with the New York Botanical Garden. The full-time faculty numbers over 400; part-time faculty, over 150 . The library has a professional staff of 17 , a supporting staff of 20 , and more than 410,000 volumes, 1,600 periodicals, and 250,000 microforms.

Please send resumes by November 1, 1983, to:

\section{Johanna Meskill \\ Chair, Search Committee \\ Herbert H. Lehman College \\ The City University of New York \\ Bronx, NY 10468}

An equal opportunity, affirmative action employer

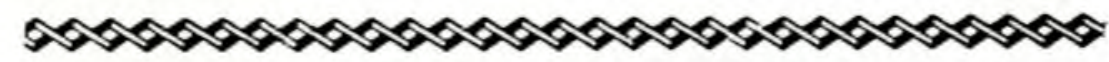

sistance in subject specialties. Receives general direction and re ports to the Head, Reference/Bibliographic Services. Receives guidance from and consults with the Director of Collections and Information Services in collection development activities Supervises designated support staff members in the Reference/Bibliographic Services Department. The Department, with a staff of twelve librarians and seven support staff plus student assistants, provides refer ence and information services in the social sciences, humanities, education, business, and government documents. The University of Cincinnati is a member of the Association of College and Research Libraries and the Center for Research Libraries. The University Libraries is in the second of a projected six-year total automation proj ect. Qualifications: MLS degree from an ALA-accredited program, undergraduate or graduate degree in one or more social sciences, or relevant combination of education and experience; demonstrated supervisory experience required; relevant library experience required; ability to communicate clearly, both orally and in writing, required; reading knowledge of a foreign language in addition to En glish desirable. Salary dependent upon qualifications and experience, minimum $\$ 16,615$. Please send resume with cover letter, salary requirement and names of three references postmarked by October 31, 1983, to: Sharon Tuffendsam, Libraries Personnel Officer, University of Cincinnati, ML \#33, Cincinnati, OH 45221. The University of Cincinnati is an affirmative action, equal opportunity employer.

ASSISTANT UNIVERSITY LIBRARIAN FOR PUBLIC SERVICES (reopened). University of Arizona Library. The assistant university librarian has administrative responsibility for ten public services departments, including three branch libraries, with a total staff of 32 professionals and more than 50 FTE of career staff and other suppor personnel. The University is located in Tucson, 60 miles north of the Mexican border, and currently enrolls some 32,000 students. The area offers a variety of cultural and recreational activitiessymphony, opera, theater, hiking, skiing, and 330-plus sun-filled days a year. Required: ALA-accredited degree and five years of professional library experience in a supervisory or administrative position in public services. Experience coordinating a large staff will be given special consideration. Familiarity with library/faculty liaison, library orientation and training programs, computer-assisted reference service, and collection development work is desirable. Position available March 15, 1984. Salary: $\$ 33,000$ minimum. Professional librarians at the University of Arizona are voting members of the faculty, have 12-month appointments, 22 days vacation, fringe benefits. Send resume, including list of three references, to: $W$. David Laird University Librarian. University of Arizona Library, Tucson, AZ 85721. Application deadline: October 15, 1983. An equal opportunity, affirmative action, Title IX, Section 504 employer

CATALOG LIBRARIAN, Albert R. Mann Library, Cornell University. Performs original descriptive and subject cataloging of both serials and monographs (also works with member-contributed copy). Subjects include many areas in agriculture, life sciences, and the socia sciences. Requirements: ALA-accredited MLS; minimum of two years professional cataloging experience; thorough knowledge of AACR2, LC classification, and subject headings; experience in the use of an automated cataloging system, preferably RLIN; subject background in agriculture and/or life sciences; knowledge of West ern European languages desirable. Rank and salary dependent upon experience and qualifications. Salary: $\$ 18,900-$ higher salary negotiable dependent on additional qualifications. Apply by October 7. 1983. Available January 1984. Send resume listing three references to: Carolyn Pyhtila, 235 Olin Library, Cornell University, Ithaca, NY 14853. Cornell University is an equal opportunity, affirmative action employer.

CATALOGER. The Los Angeles County Museum of Natural History Research Library is seeking a librarian to catalog a wide variety of book and non-book material (monographs, serials, documents, manuscripts, pamphlets, ephemera, photographs, maps) using OCLC where appropriate. This material will be housed in a newly created western history special collection. The cataloger will be re sponsible for descriptive cataloging using AACR2, subject catalog ing using Library of Congress subject headings and other thesauri, and classification using LC and other retrieval systems. Some reference work required. In addition to cataloging skill the position requires flexibility and self-direction, coupled with the ability to work closely with Museum staff. Minimum qualification: ALA-accredited MLS. Second master's degree in American history desirable. Salary: $\$ 18,000+$ depending on qualifications. Three year appointment Send resume, letter of application, and 3 references, by 30 September 1983 to: Library Search Committee, Research Library, Museum of Natural History, 900 Exposition Blvd., Los Angeles, CA 90007. An equal opportunity employer

CATALOGERS (2). Entry level new positions with responsibilities for original cataloging, editing and inputting of MARC records. First position. Catalogs materials for Nonbook and Special Collections areas. Includes printed and manuscript materials relating to Nevada gaming and culinary arts; maps; and audiovisual materials with emphasis on music. Second position. Creates serials analytics, and catalogs materials in all subjects. Requirements for both positions: ALA 
accredited library school degree, knowledge of AACR2 and LC classification and subject heading, ability to work with broad range of subjects. Knowledge of one European language and familiarity with MARC formats preferred. Salary: $\$ 16,000$. Tenure-track, faculty sta tus, 12-month appointment, 24 days vacation, fringe benefits, TIAA CREF. Send letter of application, resume and names of 3 references to: Mary Dale Palsson, Director of Libraries, University of Nevada, Las Vegas, 4505 Maryland Parkway, Las Vegas, NV 89154. Application deadline: September 30, 1983. The University of Nevada, Las Vegas is an equal opportunity, affirmative action, Title IX, 504, 402 employer.

CHINESE AGRICULTURE SUBJECT SPECIALIST, Albert R. Mann Library, Cornell University (search extended). Selection, acquisition, and cataloging of Chinese-language materials in the field of agriculture. Includes expanding an active exchange program and al aspects of cataloging monographs and serials. Provides reference service and acts as liaison with faculty and students; hosts visiting scholars. Additional responsibilities include selection and subject cataloging of Western language materials in selected areas of agricultural and life sciences. Qualifications: ALA-accredited MLS or equivalent; 3-5 years cataloging experience, which includes LC classification and subject headings. Fluency in Chinese speaking (Mandarin/Putonghua), reading and writing. Subject background or demonstrated interest in agriculture or life sciences essential. Rank and salary dependent on experience and qualifications. Salary: up to $\$ 23,400$. Apply by October 7,1983 . Available January 1984 Send resume listing three references to: Carolyn Pyhtila, 235 Olin Library, Cornell University, Ithaca, NY 14853. Cornell University is an equal opportunity, affirmative action employer.

CURATOR, UTAH AND AMERICAN WEST ARCHIVES, Lee Li brary, Brigham Young University. Responsible for collection development, processing, cataloging and reference service for archiva materials dealing with Utah and the West. Requires strong background in history of the West. Must have master's degree in archival science, history, library science or liberal arts. Ph.D. preferred. Faculty position with 12-month contract, one-month vacation. Salary: $\$ 16,300$ and up. Brigham Young University is a private institution. Applicants must be willing to abide by highest standards of honor integrity, and morality as taught by the Church of Jesus Christ of Latter-Day Saints, including abstinence from alcoholic beverages, tobacco, tea and coffee. Send letter of application, resume and names of three references by September 30,1983, to: Randy J. Olsen, Lee Library, Brigham Young University, Provo, UT 84602.

DATA COLLECTION COORDINATOR/SOCIOLOGY BIBLIOGRAPHER. Creates a Data Collection in the library of numeric and textual-numeric databases and documentation. Coordinates its activities with other units in the University and serves as ICPSR liaison. Evaluates and recommends purchase of data files, develops policy and provides reference service for Data Collection. Serves as Bibliographer for Sociology: selects, develops and evaluates subject collection; serves as liaison with Sociology Department and provides in depth library instruction; provides reference service including computer searching of sociology-related bibliographic and nonbibliographic databases. Reports to the Head, Collection Develop ment. Required: MLS from an ALA-accredited library school; graduate degree or equivalent in sociology; strong background in statistics; minimum two years experience in academic library and/or data archive; at least one years experience with data files of numeric or textual-numeric databases and demonstrated competency therein. Ability to communicate effectively with students, faculty, and library staff. Salary and rank: commensurate with education and ex perience; salary from $\$ 19,000$ depending on qualifications. Library faculty at SUNYA are expected to fulfil faculty obligations in the areas of contribution to the advancement of the profession and university service as well as specific library assignments. To apply send letter of application, current resume and names of three references to: Kevin McCarthy, Library Personnel Officer, State University of New York at Albany, 1400 Washington Avenue, Albany, NY 12222. Inquiries should be received by October 10, 1983. The State University of New York at Albany is an equal opportunity, affirmative action employer. Applications from women, minorities, and the handicapped are especially welcome.

DIRECTOR OF THE BIO-MEDICAL LIBRARY, University of Min nesota Libraries-Twin Cities. The Bio-Medical Library supports the teaching, research, and service programs of the Health Sciences on the Minneapolis campus of the University of Minnesota. These programs span the full array of health sciences disciplines and include strong outreach and service activities. The Bio-Medical Library has a total operating budget of more than $\$ 1,000,000$, approximately onehalf of which is devoted to acquisition. It has a staff of $42 \mathrm{FTE}$, including 11 professionals. It has a collection of over 300,000 cataloged volumes and receives approximately 4,000 serials. The Bio-Medical Library is located in the health sciences complex on the University's Minneapolis campus and is physically consolidated with the exception of the Natural History Library. The Bio-Medical Library includes a learning resuurces center, a major history of medicine collection, and its own processing unit. It participates in the RLIN cataloging system and utilizes its own, locally-developed serials and acquisition

\section{DEAN AND DIRECTOR OF LIBRARIES Northeastern University}

Northeastern University invites applications and nominations for the position of Dean and Director of the University Libraries. The Director is responsible for administering the total operation of the University Libraries and is expected to provide creative and effective leadership on all levels.

Northeastern University is a private, coeducational university located in Boston, Massachusetts with graduate and undergraduate programs in nine colleges. Total enrollment of all programs both day and evening is over 56,000 students.

The present libraries at Northeastern University consist of the Robert G. Dodge Library, three divisional libraries on campus, and two libraries on separate suburban campuses. The total staff consists of 35 professionals and 49 support staff. The Northeastern University libraries are designated as a depository for U.S. Government publications. Northeastern University is a member of the Boston Library Consortium and NELINET.

A new library will be built in two phases with groundbreaking for the first phase planned for late 1984.

Minimum Qualifications: 1) Accredited MLS, plus a second graduate degree, preferably a doctorate; 2) Demonstrated success in directing a major unit in an academic or research library for a minimum of five years ; 3 ) Demonstrated strong leadership and communication skills and ability to work well with staff, faculty, students, alumni, and administration; 4) Knowledge of and demonstrated initiative in current library and information technology; 5) Evidence of professional and scholarly achievement; 6) Demonstrated success as an advocate within a University or related community, within the Library community, and with potential donors; 7) Fund raising experience and experience with library building consultants and architects desirable.

Salary commensurate with qualifications. Position available on or after January 1, 1984. Send letters of nomination or application with resume and five names and addresses of references to: Dean Christopher F. Kennedy, Chair, Dean and Director of Libraries Search Committee, 126 Hayden Hall, Northeastern University, 360 Huntington Avenue, Boston, MA 02115. Deadline for receipt of nominations and applications is October 15, 1983. Northeastern University is an Equal Opportunity, Affirmative Action Employer.

\section{NORT IEASTERT UNIVERSITY}




\section{DIRECTOR, INSTITUTE OF TECHNOLOGY LIBRARIES University of Minnesota-Twin Cities}

The Director of the Institute of Technology Libraries is responsible for administering six libraries (Architecture, Chemistry, Engineering, Geology, Mathematics, and Physics) with a budget of over $\$ 1,000,000$, staff of $21 \mathrm{FTE}$, and a collection of 300,000 + cataloged volumes. The Director of the I.T. Libraries reports to the University Librarian and participates in University Libraries-wide planning and policy development, together with the Directors of the other major University Libraries departments.

A minimum of five years experience in a science or technology library is required, as is either a master's degree infibrary or information science or an appropriate advanced degree in a relevant field. Experience in a large research or academic library and an academic degree in the physical or applied sciences is desirable.

Applicants for this position must also have demonstrated skills in administration, planning, and interpersonal relations. They must have a sophisticated knowledge of information science and its application in the physical and applied sciences. They must be able to work effectively with faculty, students, academic administrators, library colleagues, and staff.

Salary for this academic-administrative position is negotiable, with a minimum of $\$ 37,500$. A full array of fringe benefits, including a retirement system and medical-dental coverage, is provided.

Applications must be postmarked by November 1, 1983. Nominations should be received by October 1, 1983. If interested in applying, please send a letter of application, vita, and names of four references to: Robert Wright, Personnel Officer, University Libraries, 499 Wilson Library, 309 19th Avenue South, Minneapolis, MN 55455.

The University of Minnesota is an equal opportunity educator and employer and specifically invites and encourages applications from women and minorities.

systems. It has extremely strong database searching and information delivery programs. The Bio-Medical Library participates in a number of national, regional, and statewide cooperative medical library programs, including the Greater Midwest Regional Medical Library Network, the Minnesota Council of Health Science Libraries and the RLG Medical and Health Sciences Program Committee. Recognized as one of the outstanding bio-medical libraries in the country, the University of Minnesota Bio-Medical Library has been a national leader in cooperative developments, information services, audiovisual applications, and interlibrary cooperation. It has one of the strongest collections among bio-medical libraries in the country. These emphases are expected to continue in the future, with particular priority on continued collection strengths, electronic information delivery, network participation, bibliographic instruction, and close interaction with the health sciences academic programs. The Director of the Bio-Medical Library reports to the University Librarian and participates in University Libraries-wide planning and program development together with the other directors of the major University Libraries departments: Central Administrative Services, Central Technical Services, Institute of Technology Libraries, St. Paul Campus Libraries, Walter Library, and Wilson Library. The Bio-Medica Library Director is an ex-officio member of the Bio-Medical Library Committee, which meets regularly to advise regarding the programmatic directions of the Bio-Medical Library. Applicants for this position must have a minimum of five years experience in a major biomedical library or libraries, demonstrated successful management experience, and MLS or appropriate equivalent academic preparation. In addition, applicants should have demonstrated skills in administration, planning and interpersonal relations. They should have sophisticated knowledge of the library services requirements of the health sciences and be able to work effectively with faculty, students, academic administrators, library colleagues and staff. Highly desirable: an academic background in a health sciences related field; Medical Library Association certification; leadership potential in the areas of library automation; networking; continuing education and outreach activities; electronic information delivery; knowledge of and participation in research projects; scholarly publishing and presentations. This is an academic administrative position. Salary is negotiable, with a minimum of $\$ 40,000$. Applications must be postmarked by Sepiember 30, 1983. Please send letter of application, vita, and the names of four references, to: Robert Wright, University Libraries Personnel Officer, 499 Wilson Library, 309 19th Avenue South, Minneapolis, MN 55455. The University of Minnesota is an equal opportunity educator and employer and specifically invites and encourages applications from women and minorities.

DIRECTOR OF THE LIBRARY. Frostburg State College, a fouryear college offering twenty-nine undergraduate majors and seven master's degrees in liberal arts and professional studies, seeks a di rector to provide creative leadership in keeping the library at the center of the educational program. Excellent facilities, 200,000 volumes plus government document depository and multi-media materials, staff of 31 and annual budget approaching $\$ 800,000$. Twelve month appointment, salary $\$ 24,714-\$ 32,462$, open January 1,1984 . ALA accredited MLS and seven years administrative experience in academic librarianship required. Commitment to library use promotion and working familiarity with library automation, networking and budgeting required. Full description available upon request. Send application letter, resume, and three confidential reference letters by October 1, 1983, to: James Cotton, Library Director Search Commit tee, Frostburg State College, Frostburg, MD 21532. Equal opportunity, affirmative action employer.

EDUCATIONAL RESOURCES CATALOGER (search extended) Ball State University. Reports directly to the senior educational resources cataloger. Responsible for: descriptive and subject cataloging of all non-print formats using AACR2 rules and OCLC/MARC formats and Library of Congress subject headings and practice assisting in staff training and supervision, cataloging revision of technical and cataloging assistants, participation in planning, develop ment, policy-making, and evaluation within the Educational Resources Technical Services area. Requirements: MLS degree from an ALA-accredited program or equivalent in instructional media. Preference will be given to applicants with: a minimum of two years of cataloging experience, including one year of audiovisual catalog ing; experience in using AACR2, OCLC/MARC and Library of Con gress subject and educational technology; broad range of experience with non-print media. Desire evidence of strong commitment to media/library services and potential for scholarly and professional achievements. Academic year appointment with possible additional summer appointment, good fringe benefits; salary negotiable from $\$ 13,000$. Possible tenure and faculty rank and status. Applications must be postmarked no later than September 30, 1983. Send resume and list of references to: Nyal Williams, Chairman of the Department of Library Service, Ball State University, Muncie, IN 47306 Ball State University practices equal opportunity in education and employment.

HEAD, ACQUISITIONS DIVISION. Responsible for planning, policy, procedures, supervision, and administration of the Acquisitions Division that includes all serials activities, OCLC automated acquisition system, and binding operations. Monitors State book and binding contracts. Participates in decision making with other division heads. Acquisitions Division is composed of four units: Binding Department, Serials Records, and Monographic and Serial Ordering and Receiving. The Division staff consists of three librarians and 24 classified staff. The Library has a materials budget of $\$ 2.3$ million; a staff of 54 librarians and 141 classified staff; and holdings consisting of 1.3 million volumes, 15,347 subscriptions, and 1.2 million microforms. Texas A\&M University has an enrollment of 36,000 and is located in the Bryan-College Station Community of 90,000 residents; 90 miles from Houston and Austin. Qualifications: ALA/MLS and a 
minimum of seven years of relevant post-MLS professional library experience, preferably in an academic library. Familiarity with OCLC acquisitions subsystem or other automated acquisitions systems preferred. Open September 1, 1983. Salary: $\$ 23,000$ minimum for 10.5 mos., negotiable. Benefits include insurance package, retirement plan options, $88 \%$ of social security paid on first $\$ 16,500$ of salary, no state or local income taxes, 13 state holidays, faculty rank. To apply contact: Kristen M Dahlen, Head, Personnel Operations, University Library, Texas A\&M University, College Station, TX 77843. An AA/EEO employer.

HEAD LIBRARIAN (search reopened), Director of the Library Learning Center and Chairperson of the Library Science Department Twelve-month, tenure-track appointment. Salary range, $\$ 22,000-\$ 26,000$ for appointment at rank of Assistant or Associate Professor of library science, dependent upon qualifications. Excellent fringe benefits. Kentucky Wesleyan College offers a bachelor's degree in library science. Six years of college library experience required. Must hold a master's degree in library science from an accredited ALA library school. Preference will be given to the doctora candidate. Appointment to become effective September 1, 1983, if candidate is available; if not, January 3,1984 . Send resume, tran scripts, and letters of recommendation by September 30, 1983, to: Donald D. Douglass, Kentucky Wesleyan College, Owensboro, KY 42301. Equal opportunity employer.

HEAD OF MONOGRAPHS. Position available approximately Jan 1984. Responsible to Asst. Director of Technical Services for al monographic activities, including cataloging, catalog maintenance acquisitions and physical processing (over 600,000 volumes). Major emphasis: cataloging (Asst. Director retains supervision of acquisitions for about first year), development of written procedures, subject catalog maintenance, performance of original cataloging, supervision of 3.5 professional and 11 support staff. Minimum qualifications: ALA-accredited MLS; 5 years varied, recent professional experience in cataloging in academic or research library; supervision of

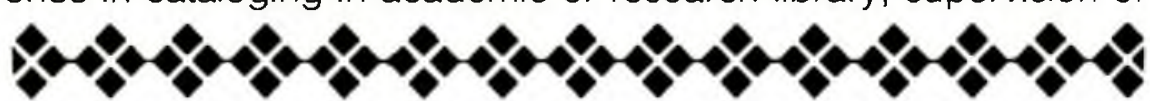

\section{HEAD, SCIENCE LIBRARIES}

\section{Berkeley}

Administer 14 life and physical science branch libraries in the General Library system, UC Berkeley, with responsibility for personnel and fiscal management including a $\$ 1$ million acquisition budget. Supervise public service, technical processing, and collection development. Responsible for development of automated programs, faculty relations, and outside funding sources.

Requires MLS degree, extensive and increasingly responsible experience in a scientific, biomedical, or engineering academic library, and demonstrated effective management skills. Experience with library instructional programs, computer literature searching, automated catalog processing, and experience in collective bargaining highly desirable.

Full job description mailed on request. Salary range from $\$ 26,608$ per annum to start, depending on qualifications. Starting date 1 November 1983, as soon thereafter as possible. To apply send resume, including names and addresses of three professional references, by 30 September 1983 to:

\section{William E. Wenz \\ Library Personnel Officer \\ Room 447 General Library \\ University of California \\ Berkeley, CA 94720}

\section{An equal opportunity, affirmative action employer}

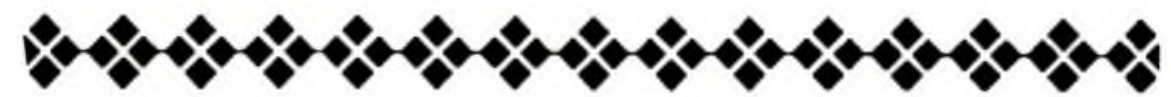

full-time staff; experience with AACR2, LC subject headings; original cataloging and OCLC cataloging subsystem. Preferred: experience in monographic acquisitions; two foreign languages of bibliographic importance. Salary: $\$ 19,200$ minimum. Rank and salary commensurate with experience and qualifications. Deadline: Oct. 15, 1983 Send resume and 3 names of reference to: Brian Ruddick, Chair Search Committee, Cleveland State University Libraries, $1983 \mathrm{E}$ 24th St., Cleveland, OH 44115. Equal opportunity employer, M/F/H.

HEAD, TECHNICAL SERVICES. Selective liberal arts college seeks a multi-talented and experienced librarian to head its acquisitions/cataloging operations and to make a significant contribution to its automation planning. Includes responsibility for some original cataloging, supervision of 3 support staff and 8-10 student assistants, and a retrospective conversion project. The head of Technical Services also does some reference work, some bibliographic instruction, and some liaison work with academic departments. Qualifications: ALA-accredited MLS, three years experience, working knowledge of OCLC, AACR2, and LC classification. Preference given to candidates with some combination of: knowledge and/or experience with library automation, reading knowledge of foreign language(s), interest in bibliographic instruction, background in business, computer sciences, or natural sciences. Faculty status; excellent fringe benefits. Salary competitive, minimum $\$ 18,000$. Send resume and three current letters of reference to: Peter Dollard Director, Alma College Library, Alma, MI 48801. Application deadline is October 3. Equal opportunity, affirmative action employer.

INTERLIBRARY SERVICES LIBRARIAN. 12-month, tenure-track appointment, available October 18. Responsible for interlibrary borrowing and lending activites of the University of Kansas Libraries. Supervises staff of 4 plus approximately 90 hours per week of student hourly help. Includes some reference desk duty. Requires ALA accredited MLS; at least one year of academic library experience (paraprofessional or professional level); ability to work effectively with library patrons, staff, and ILS personnel at other institutions. Pre fer broad knowledge of bibliographic tools and of Western European languages; interlibrary services or related experience; and supervisory experience. Salary: $\$ 16,000-\$ 18,000$, dependent upon qualifi-

\section{INSTRUCTIONAL SERVICES LIBRARIAN}

Responsible for planning and administering the Library's instructional program. Coordinates the library components of $\mathrm{Ba}$ sic Skills instruction and other college wide programs. Some evening service required. Applicants must have an MLS from an ALA-accredited institution, second master's degree and experience in comparable library instruction program. To receive tenure, a significant record of professional activity, including publication, must be achieved. Appointment as Assistant Professor ( $\$ 21,650$ plus) depending on qualifications.

Twelve-month contract, 30 working days vacation, excellent health and retirement programs. Send resume by September 30, 1983, to:

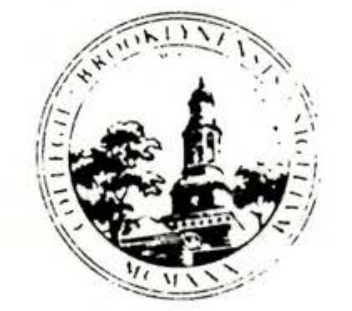

Chief Librarian Brooklyn College Brooklyn, NY 11210

An EO/AA Employer M/F 
cations. Send letter of application, resume, and names of 3 references, to: Mary Hawkins, Assistant Dean, University of Kansas Libraries, Lawrence, KS 66045. Postmark deadline for applications: September 30. An equal opportunity, affirmative action employer.

JUDAICA CATALOGER. Begin October 1983. Requirements: MLS/ALA, LC classification, OCLC and AACR II and two or more years cataloging experience. Hebrew a must. $\$ 14,000$ minimum Send resume to: Sarah Levy, Librarian, Dropsie College, Broad \& York Sts., Philadelphia, PA 19132

MANUSCRIPT CURATOR FOR PAUL MILLER PAPERS with faculty rank. Process the papers in accordance with recognized princiulty rank. Process the papers in accordance with recognized princi-
ples for preserving and providing access to manuscript collections; provide assistance to users of the collection; develop machinereadable indexing to the materials. Master's degree from an ALAaccredited library school; training and practical experience in the care and administration of manuscript collections and in preparation of machine-readable indexes; demonstrated competency in skills necessary to communicate, supervise, organize, analyze, and plan effectively. This is a specially funded appointment. Good fringe benefits; 22 working days vacation and 8 holidays. Salary: $\$ 16,500-\$ 22,500$ depending upon experience. For full consideration, applications should be received by October 1, 1983. Submit letter of application with resume including names of three references to: Roscoe Rouse, University Librarian, Oklahoma State University, Stillwater, OK 74078. AA/EO employer.

PERIODICALS LIBRARIAN, anticipated vacancy. Responsible for acquisition of periodicals, evaluation and maintenance of collection including cataloging/classification of new/changed titles in all subject areas, union listing of holdings online and supervision of binding. Required: master's ALA-accredited degree, 3-5 years experience with periodicals collection and serials cataloging using OCLC, AACR2 LC class schedules and subject headings. Preferred: knowledge of union-listing; supervisory experience; good interpersonal skills. Salary: $\$ 15,786-\$ 20,719$. Send letter of application, resume, placement file and three letters of reference by October 1 ; 1983, to: John Zimmerman, Director of the Library, Frostburg State College, Frostburg, MD 21532. AA/EOE.

PUBLIC SERVICES COORDINATOR. The University of Wisconsin-La Crosse is seeking applications from experienced librarians for the position of public services coordinator, to begin January 9,1984 . Duties include working on daily basis with library personnel in reference, circulation, bibliographic instruction, special collections, interlibrary loan, and government documents to coordinate planning and to implement new services. Will assist in reference desk service with some night and weekend assignments. The professional librarians are organized as a department of the faculty. Applicants must be prepared to participate in collegial governance affairs of the library department. ALA-accredited MLS degree required additional graduate work and science background desirable. Minimum of five years professional experience in an academic library with demonstrated experience and knowledge of public service, database searching and library computer automation. Salary from $\$ 25,000$ depending on qualifications and experience, for academic year, tenure track faculty position. Deadline for submission of applications, October 20,1983. Send resume, names of three professional references and credentials to: Edwin Hill, Department Chairperson, Murphy Library, University of Wisconsin-La Crosse, La Crosse, WI 54601. An affirmative action, equal opportunity employer.

RARE BOOK CURATOR for privately-endowed historical society Requirements: MA in history or equivalent; MLS from ALA accredited institution with concentration in bibliography and rare books; 2-5 years experience in rare book acquisitions and cataloging; knowledge of conservation and microfilming techniques. Salary range: $\$ 16,000$ minimum. Send letter of application, resume, and names of three references to: Christopher $P$ Bickford, Director, The Connecticut Historical Society, 1 Elizabeth St., Hartford, CT 06040.

REFERENCE LIBRARIAN, Albert R. Mann Library, Cornell University. Under the direction of the Head of Reference, provides the full range of reference services using print and online sources and pre pares library publications. Develops collegial interactions with faculty which form the basis for participation in bibliographic instruction and collection development in assigned subject areas. Instruction includes teaching end-users to utilize bibliographic databases. Qualifications: ALA-accredited MLS. Interest in the development of an active public services program required. Experience in reference bibliographic instruction, computer searching, and collection development desirable. Subject expertise or demonstrated interest in agriculture or life sciences highly desirable. Rank and salary dependent on experience and qualifications. Salary: \$16.688-higher salary negotiable dependent on additional qualifications. Apply by October 7, 1983. Available January 1984. Send resume listing three references to: Carolyn Pyhtila, 235 Olin Library, Cornell University, Ithaca, NY 14853. Cornell University is an equal opportunity, affirmative action employer.

REFERENCE LIBRARIAN In addition to the duties outlined in the reference position described above, is responsible for managing a small branch library in entomology. Includes hiring, training, and supervising student assistants, providing information services to entomology students and faculty. Qualifications: minimum of two years reference experience required, in addition to those listed for above position Demonstrated knowledge of the information requirements of scientists, and supervisory experience highly desirable. Rank and salary dependent on experience and qualifications. Salary $\$ 18,900$ - higher salary negotiable dependent on additional qualifications. Apply by October 7, 1983. Available January 1984. Send resume listing three references to: Carolyn Pyhtila, 235 Olin Library,

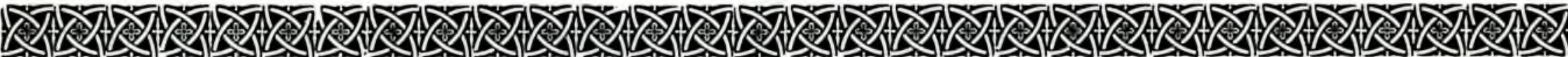

\section{LIBRARIAN FOR GERMANIC COLLECTIONS University of California, Berkeley}

Develop and maintain Germanic publications in the humanities, social sciences and interdisciplinary scientific fields. Consult with faculty and provide reference service and bibliographic assistance to users. Perform original cataloging of monographs in German. Will use database searching techniques for both reference and cataloging.

Requires MLS degree and fluent knowledge of German. Substantial knowledge of Germanic language, literature, culture, publishing and book trade highly desirable. Candidates should have successful previous experience in reference and cataloging relevant to this assignment. Full job description mailed on request.

Salary range from $\$ 21,288-\$ 24,984$ per annum to start depending on qualifications. Starting date 1 November 1983 or as soon thereafter as possible. To apply send resume, including names and addresses of three professional references, by 20 September 1983, to:

\author{
William E. Wenz, \\ Library Personnel Officer \\ Room 447 General Library \\ University of California \\ Berkeley, CA 94720
}

An equal opportunity, affirmative action employer.

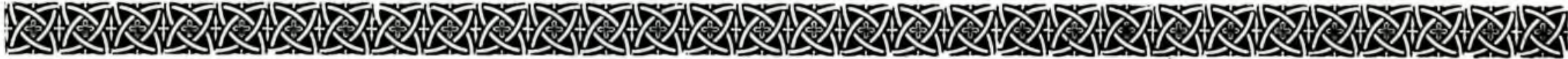


Cornell University, Ithaca, NY 14853. Cornell University is an equal opportunity, affirmative action employer.

REFERENCE LIBRARIAN. Provides reference and computer search services to library users during scheduled hours, including evening and weekend hours. Conducts online searches of bibliographic and non-bibliographic databases. Participates in policy development and contributes to the development and improvement of reference services. Required: MLS from an ALA-accredited library school; at least two years recent reference experience in an academic library. Preferred: experience with online bibliographic databases; business or science background. Salary and rank: commensurate with education and experience; salary from $\$ 16,500$ depending on qualifications. Library faculty at SUNYA are expected to fulfill faculty obligations in the areas of contribution to the advance ment of the profession and university service as well as specific library assignments. To apply send letter of application, current resume and names of three references to: Kevin McCarthy, Library Personnel Officer, State University of New York at Albany, NY 12222. Inquiries should be received by October 10, 1983. The State University of New York at Albany is an equal opportunity, affirmative action employer. Applications from women, minorities and the handicapped are especially welcome.

REFERENCE LIBRARIAN AND BIBLIOGRAPHER. Responsibilities: Reference service (with evening and weekend rotation), online bibliographic searching, library orientation/instruction, collection development and faculty liaison work. Areas of specialization: science and technology. ALA-accredited library school degree required Good communication and interpersonal skills and ability to work well with public and staff essential. Undergraduate courses in the sci ences and familiarity with online searching desired. Hiring salary $\$ 16,000$. Tenure-track, faculty status, 12-month appointment, 24 days vacation, fringe benefits, TIAA/CREF. Submit letter of application, resume names of three references by September 30,1983, to: Mary Dale Palsson, Director of Libraries, University of Nevada, Las Vegas, 4505 Maryland Parkway, Las Vegas, NV 89154. The University of Nevada, Las Vegas is an equal opportunity, affirmative action employer

REFERENCE LIBRARIAN/BIBLIOGRAPHER. 12-month, tenure track appointment. Primary responsibility is general reference ser vice to undergraduate and graduate students and faculty in the humanities, social sciences, and related professional fields. Participates in library orientation and instruction and conducts online searches. Also responsible for cooperative collection development projects in the social sciences as well as the continuing development of a major collection supporting an active academic program in women's studies. Reference Department offers collegial environment with independent working situations and flexibility in future as signments. Requires ALA-accredited MLS, strong subject back ground in social sciences other than history, ability to work effectively with library users and staff, and knowledge of at least one foreign language (Western European). Prefer research library experience in reference, collection development, and online searching; advanced study in social sciences or related field particularly women's studies. Salary: $\$ 15,000-\$ 20,000$ dependent upon qualifications. Send letter of application, resume, and names of 3 references to: Mary Hawkins, Assistant Dean, University of Kansas Libraries, Lawrence, KS 66045. Postmark deadline for applications: September 30, with starting date as soon as possible thereafter. An equal opportunity, affirmative action employer.

SOCIAL WORK LIBRARIAN. The position of librarian, Whitney $M$ Young Jr. Memorial Library of Social Work, reports to the chief of the Social Science Division and has primary responsibility for formulat ing and implementing policies regarding the development and preservation of the Social Work Library collection, a major research facility of some 120,000 printed volumes, and for providing all levels of reference and consultation services to students and faculty, including orientation and instructional services. The incumbent will also serve as liaison between students, faculty and administration of the School of Social Work and the Libraries, participate in the Social Science Division planning and policy activities and provide input into the formulation and implementation of access and technical services policies of the Lehman/Social Work library complex. In addition to an accredited MLS, requirements are previous relevant professional experience in a large academic or research library and a strong background in the literature of social welfare and of the social sciences. Previous experience in searching bibliographic databases is highly desirable. Ability to function independently and to work effectively with faculty and students is essential. Submit resume, listing 3 references and salary requirements to: Box 35, Butler Library, Columbia University Libraries, 535 West 114th Street, New York, NY 10027. Salary ranges: Librarian II, \$20,000-\$26,000; Librarian III: $\$ 23,000-\$ 33,350$. Deadline for applications is September 30, 1983 An aftirmative action, equal opportunity employer.

STATE LIBRARIAN, Library of Michigan. Master's degree in library science with a minimum of 4 years' experience in library work in an administrative capacity required. The Library of Michigan, with a staff of 105 and over 1,500,000 volumes, serves the legislature and all of state government and local and school libraries and includes a law library Send resume to: Legislative Service Bureau, Elliott Smith, Secretary, Legislative Council, P.O. Box 30036, Lansing, MI 48909, prior to October 3, 1983. An equal opportunity employer.

COORDINATOR, INFORMATION SERVICES. Depauw University is seeking ... an experienced and innovative public services librarian to work with faculty and students to expand reference and information services in its main and branch libraries. Responsibilities include management of the reference department ( 3 FTE's, 2 professional) and the continued development of reference/information services, online searching, interlibrary loan, bibliographic instruction, and collection development. The position will also coordinate the 1ibrary's departmental liaison/information specialist program, in which each professional on the library staff works with several academic departments to assist with collection development and provide library support for individual classes. Required: an ALA-accredited MLS; substantial professional experience (5+ years) in public/information services; proven reference and supervisory capability; leadership ability with strong interpersonal and communication skills; demonstrated competence in assessing needs and designing and implementing services; and online searching experience. Desirable qualifications include a science academic background or strong experience with scientific information sources and collection development experience. The position is available January 2, 1984, and offers faculty rank and status, $\$ 22,000$, and excellent fringe benefits. Send a letter of application, a resume, and the names of three to five references to: Jana Bradley, Director of Libraries, P.0. Box 137, DePauw University, Greencastle, IN 46135. Deadline for applications: November 1, 1983. An affirmative action, equal opportunity employer. 
REFERENCE LIBRARIAN/INFORMATION SPECIALIST. DePauw University is seeking an innovative public services librarian to participate in the development of expanded information services. Responsibilities will include providing both traditional and outreach reference and information services, online searching, and user instruction. The position also serves as an information specialist to several academic departments, assisting with collection development and providing library support for individual classes. Required: an ALA-accredited MLS, reference experience in an academic library, experience with online searching, and strong interpersonal and communication skills. A second masters degree or a strong subject speciality is highly desirable. The position is available January 2, 1984, and offers faculty rank and status, $\$ 16,000$, and excellent fringe benefits. Send a letter of application, a resume, and the names of three to five references to: Jana Bradley, Director of Libraries, P.0. Box 137, DePauw University, Greencastle, IN 46135. Deadline for applications: November 1, 1983. An affirmative action, equal opportunity employer.

ASSISTANT CATALOG LIBRARIAN. Duties will include cataloging A/V materials, music scores, and original cataloging and classification of monographic publications; general departmental duties such as revision of filing in shelflist and card catalog; materials selection. Required: MLS from ALA-accredited graduate school; reading knowledge of at least one modern European language; knowledge of LC classification and AACR2; experience with OCLC online procedures. Twelve-month appointment, rank of lecturer (non-tenure track). Usual fringe benefits including 23 days annual leave. Beginning salary range: $\$ 14,400-\$ 14,700$. Apply with current resume including names of at least three references to Eugene W. Huguelet, Director of Library Services, Randall Library, University of North Carolina at Wilmington, 601 South College Road, Wilmington, NC, 28403-3297. For further information related to the position, call Director of Library Services, (919) 791-4330, ext. 2271. Closing date for applications: October 14, 1983. An equal opportunity, affirmative action employer.

ASSISTANT REFERENCE LIBRARIAN. Duties will include general reference service, bibliographic instruction, online bibliographic searching, and materials selection. Required: MLS from ALA-accredited graduate school and ability to interact effectively with all library users. Ability and interest in online searching and some experience in academic library reference service and instruction desirable. Some night and weekend hours necessary. Twelve-month appointment, rank of lecturer (non-tenure track). Usual fringe benefits including 23 days annual leave. Beginning salary range: $\$ 14,400-\$ 14,700$. Apply with current resume including names of at least three references, to: Eugene W. Huguelet, Director of Library Services, Randa11 Library, University of North Carolina at Wilmington, 601 South College Road, Wilmington, NC 28403-3297. For further information related to the position, call Director of Library Services, (919) 791-4330, ext. 2271. Closing date for applications: October 14, 1983. An equal opportunity, affirmative action employer.

REFERENCE LIBRARIAN required for reference position with special emphasis on information service in the sciences and engineering. Duties and responsibilities include general reference work on a staff with six other librarians, liaison with faculty, planning and conducting online computerbased literature searches with other science and engineering reference librarians and bibliographic instruction to class and seminar groups in those academic fields. Qualifications: applicants must possess an MLS degree and an undergraduate education in science or engineering. Previous experience in reference and online computer literature searching of science databases is required. Salary: $\$ 17,000-\$ 18,000$ depending on experience and 
qualifications. Position carries academic status, non-tenure track. The D.H. Hill Library is an ARL Library. Applications for this position must be received by October 15, 1983, in order to receive consideration. Apply with resume and names of 3 references to: William C. Lowe, Assistant Director for Reference Services, D.H. Hill Library, North Carolina State University, P.0. Box 5007, Raleigh, NC 27650. An equal opportunity, affirmative action employer.

DOCUMENTS LIBRARIANS. Two positions available to assist Head of federal Documents Department at the D.H. Hill Library, North Carolina State University. 1) Documents librarian with 2 or more years experience in a federal documents depository library. Duties include reference service, technical processing, class instruction and online bibliographic searching involving federal documents, microforms, U.S. patents, technical reports, and maps. Strong communication skills required. Some supervisory experience preferred. Salary: $\$ 17,000-\$ 18,000$, depending upon experience and qualifications. 2) Documents librarian who must be familiar with the federal depository System and possess basic knowledge of documents reference sources. An entry level position. Salary: $\$ 15,000-\$ 16,000$, depending upon qualifications. Both positions require MLS degree and will be available January 1, 1984. Positions have academic status, non-tenure track. The D.H. Hill Library is an ARL 1ibrary. The Documents Department contains over 650,000 items and nearly 2 million microforms. It is a patent depository library. Send letter of application with resume by October 15, 1983, to: William C. Lowe, Assistant Director for Reference Services, D.H. Hill Library, North Carolina State University, P.0. Box 5007, Raleigh, NC 27650. An equal opportunity, affirmative action employer.

SERIALS CATALOGER (new position). Duties are to assist in original/shared descriptive cataloging and classification of print and microform serials in all subjects and languages for the general collection and five school libraries, using AACR2, LC classification and subject headings, and OCLC guidelines; to assist in authority control work; and to share in the supervision and training of serials cataloging paraprofessionals. The D.H. Hill Library is a large, academic research library and an OCLC/SOLINET/TRLN participant. Qualifications: MLS from ALA-accredited library school, working knowledge of at least one foreign language, good communication skills, adaptability to change. Experience in supervision and the cataloging of serials highly desirable. Salary: $\$ 14,500$. Liberal state benefits and leave. Deadline for applications: 0ctober 15, 1983. Apply with resume and the names of 3 references to: Gloria W. Houser, Head, Serials Department, D.H. Hill Library, North Carolina State University, P.0. Box 5007, Raleigh, NC 27650. An equal opportunity, affirmative action employer.

HEAD, SERIALS UNIT. Primarily responsible for management and organization of serials, check-in, serials records, serials invoice payment, Periodicals Reading Room, and microfiche serials listing. Reports to Head of Acquisitions Department. Requirements: ALA-accredited masters degree, two years experience with serials and/or acquisitions, supervisory and OCLC experience. Desired: knowledge of a foreign language, academic library experience, experience with serials automation and retrospective conversion. Salary: minimum $\$ 17,040$, negotiable depending on qualifications and experience. 12-month tenure track appointment, faculty rank, TIAA/CREF. Kansas State University is a land-grant institution located in north central Kansas with an enrollment of approximately 19,000 students. Send letter of application, resume, names, addresses and phone numbers of three current references, to: Ann Scott, Administrative Services, Kansas State University Libraries, Kansas State University, Manhattan, KS 66506. Application deadline: October 1 , 
1983. Kansas State University is an equal opportunity, affirmative action employer.

CATALOG LIBRARIAN. Position open now. Responsible for cataloging library material in all formats with emphasis on media. Knowledge of automated library systems, OCLC, AACR2, LC classification, and one foreign language required; subject master's desirable. Some evening and/or Saturday work probable. Benefits: faculty rank, TIAA/CREF, paid Blue Cross/Blue Shield, major medical, tuition remission plan, 40 vacation/professional/personal days. Salary: $\$ 16,000-\$ 17,000$. Send resume and names of three current references by September 26, to: Howard Graves, Search Committee Chairman, Catalog Department, Hofstra University Library, Hempstead, NY 11550. Hofstra is an affirmative action, equal opportunity employer.

ASSOCIATE DIRECTOR FOR COLLECTION SERVICES. The Milton S. Eisenhower Library invites applications and nominations for the position of Associate Director for Collection Services. The responsibilities include oversight and direction of collection development policies and procedures, as well as allocation of the materials budget (currently $\$ 1.4$ million). Maintains close contact with campus-wide academic planning in order to relate library collection development policy to ongoing research and instruction. The Associate Director for Collection Services is responsible for the daily operations of the Collection Development Center, the Collections Maintenance Office (preservation), and the Collections Organization Unit. In addition, the Associate Director for Collection Development coordinates the collection development activities of librarians with responsibility for particular areas of the collection. The Associate Director for Collection Services reports to the Director of the Library and works closely with the Director and the Library's Administrative Committee in the overall administration of the library. Candidates must have an MLS from an accredited library school, or its equivalent. A strong academic background and a broad bibliographical knowledge are needed. Applicants must have a minimum of five years experience in positions of increasing responsibility in collection development or reference/book selection. Excellent benefits. Salary commensurate with qualifications and experience. Send resume by September 26, 1983, indicating position applied for to: Edward S. Warfield, Johns Hopkins University, Office of Personnel Services, Room 146 Garland Ha11, Baltimore, MD 21218 . Affirmative action, equal opportunity employer.

SCIENCE REFERENCE LIBRARIAN AND SUPERVISOR OF ONLINE DATABASE SEARCHING. Primarily responsible for coordination and active development of database searching program to include searching, training, marketing, evaluating, selecting material and equipment and records keeping. Provide daily reference services in Reference Department, teach effective library use in scientific and agricultural literature, participate in collection development, assume bibliographic instruction and liaison responsibilities. Required: ALA-accredited masters, three years academic library experience, extensive database searching experience, demonstrated ability to communicate effectively with faculty, staff, and students. Undergraduate degree in agriculture or life science desirable. Salary: $\$ 17,400$ minimum, negotiable, depending on qualifications and experience. 12-month tenure appointment; faculty rank, TIAA/CREF. Kansas State University is a land-grant institution located in north central Kansas with an enrollment of approximately 19,000 students. Send letter of application, resume, names, addresses and phone numbers of three current references, to: Ann Scott, Administrative Services, Kansas State University Libraries, Kansas State University, Manhattan, KS 66506. Application deadline: October 1, 1983. Kansas State University is an equal opportunity, affirmative action employer. 
BUSINESS/ECONOMICS REFERENCE LIBRARIAN. Duties: Under the general direction of the Head of Reference this position provides reference and bibliographic service in fields of business and economics; provides general reference service at the Library's Main Reference Desk; participates in collection development activities in the above subject areas; performs online bibliographic searches; and participates in library instruction including general tours and specific subject-oriented presentations. Qualifications: Required: MLS from ALA-accredited library school; academic background in business, economics, or related field or library experience in business or economics; knowledge of database searching and library instruction concepts and methods. Preference may be given to cadidates with MBA or subject masters in business, economics, or related field. Deadline for applications: October 15, 1983. Available: December 1, 1983. Salary: $\$ 16,000-\$ 20,000$. Applications: Send letter of application with resume and names of three references including current supervisor, to: Rodney M. Hersberger, Assistant to the Dean for Administrative Services, University Library, University of Oklahoma, Norman, OK 73019. The University of Oklahoma is a equal opportunity, affirmative action employer.

CATALOG LIBRARIAN. Michigan Technological University is on the OCLC system. The collection is predominantly in the sciences and engineering. Responsibilities include: classifying and cataloging of library materials, including microforms and audio-visual material, using AACR2, LC classification and subject headings, preparing and tagging cataloging data for input into OCLC; verifying and preparing authority records, and assisting in retrospective conversion. Qualifications: MLS from ALA-accredited library school. Salary: $\$ 16,000$ minimum. Application deadline: October 1, 1983 . Send resume and three letters of reference to: Lee J. Lebbin, Director, University Library, Michigan Technological University, Houghton, MI 49931. Michigan Technological University is an equal opportunity educational institution, equal opportunity employer.

COORDINATOR, TECHNICAL SERVICES, Eastern Michigan University Library • Coordinate a11 functions of the Technical Services Unit, including acquisitions/processing and cataloging; coordinate planning for technical services automation; coordinate staff of five faculty and 16.5 clerical employees. Required: MLS (ALA-accredited); graduate work in a subject discipline; seven years of applicable professional experience, including three years in a leadership role; substantive knowledge of, and direct or closelyrelated experience with all aspects of technical services, including current cataloging, acquisitions, library accounting, and automated systems planning; thorough current knowledge of OCLC or other major bibliographic utility; demonstrated problem-solving and communications skills; record of scholarship and professional service consistent with faculty promotional requirements. Tenure-track appointment at the rank of Assistant or Associate Professor. Starting Salaries: Assistant Professor- $\$ 17,800$; Associate Professor- $\$ 21,000$ academic year. Possible Spring or Summer Session appointment at $22 \%$ of base salary. Deadline date for the recelpt of completed applications is october 1 , 1983. A standard application is required in order to be considered. The form may be obtained from and must be returned to: Eastern Michigan University, Personnel Office, 310 King Hall, Ypsilanti, MI 48197; (313) 487-3430. Affirmative action, equal opportunity employer and educational institution.

HEAD PUBLIC SERVICES LIBRARIAN. Manages the circulation, reserves, and information functions, and provides general directions for stacks maintenance operations. Supervises 10 FTE support staff; writes policy and procedural documents; interprets and implements library rules; selects, trains and guides personnel; provides direct service as working supervisor, including some 
nights and weekends. Serves on the library's reference team providing regular back-up reference service, including database searching. MLS or equivalent training and experience; demonstrated administrative/managerial ability; working familiarity with academic/business library procedures; successful supervisory experience; superior public relations skills; effective oral and written communication ability; experience with circulation and public service; positive public service and staff relations attitude; ability for independent judgment and action yet acceptance of directions are needed. Salary: $\$ 26,000-\$ 30,000$ (depending upon qualifications). Associate Librarian/Librarian academic staff rank. Apply to: Search Committee, J. Hugh Jackson Library, Graduate School of Business, Stanford University, Stanford, CA 94305. An equal employment opportunity through affirmative action.

HEAD, COPY CATALOGING DEPARTMENT. Responsible for coordinating and directing work of the Copy Cataloging Department in processing materials with LC and OCLC member-input copy. Interviews, selects and evaluates staff, develops training programs and supervises training of staff, and facilitates the flow of materials through Copy Cataloging. Formulates and interprets cataloging policies and procedures in consultation with the Original Cataloging Department and the Processing Division Head. The Processing Division consists of 33 classified employees (27 of which are in Copy Cataloging) and 11 librarians. Qualifications: ALA-accredited MLS. Requires demonstrated supervisory and management skills; a minimum 3 years post-MLS professional cataloging experience; practical knowledge of OCLC or a similar bibliographic utility, LC classification and subject headings, AACR and AACR2. Benefits: Package includes $\$ 70 /$ month paid on health, 1ife, and disability insurance; $88 \%$ of social security paid for first $\$ 16,500$ of salary; choice of retirement plans including TIAA-CREF; no state or local income taxes; 10.5 month appointment, faculty rank; 13 state holidays. Salary: $\$ 18,000$ minimum, negotiable. Contact: Kristen M. Dahlen, Head, Personnel Operations, Texas A\&M University Library, College Station, TX 77843. An AA/EEO employer.

A Tri-Chapter ACRL meeting, sponsored by the Delaware Valley, New Jersey, and Greater New York Metropolitan Area chapters, will be held in Princeton on October 28. A keynote address on the theme, "Life on the Technology Express," will raise questions about technology's influence in the affairs of humans and academic institutions, and help conferees establish a common framework for examining the assumptions and values implicit in technological developments. Conferees will then be asked to apply their knowledge and insights in the analysis of a case study commissioned for the program. Fee: $\$ 25$ for chapter members, $\$ 35$ for non-members. Contact: Caroline Coughlin, Associate Director, Rose Memorial Library, Drew University, Madison, NJ 07940; (201) 377-3000, ext. 322 . 


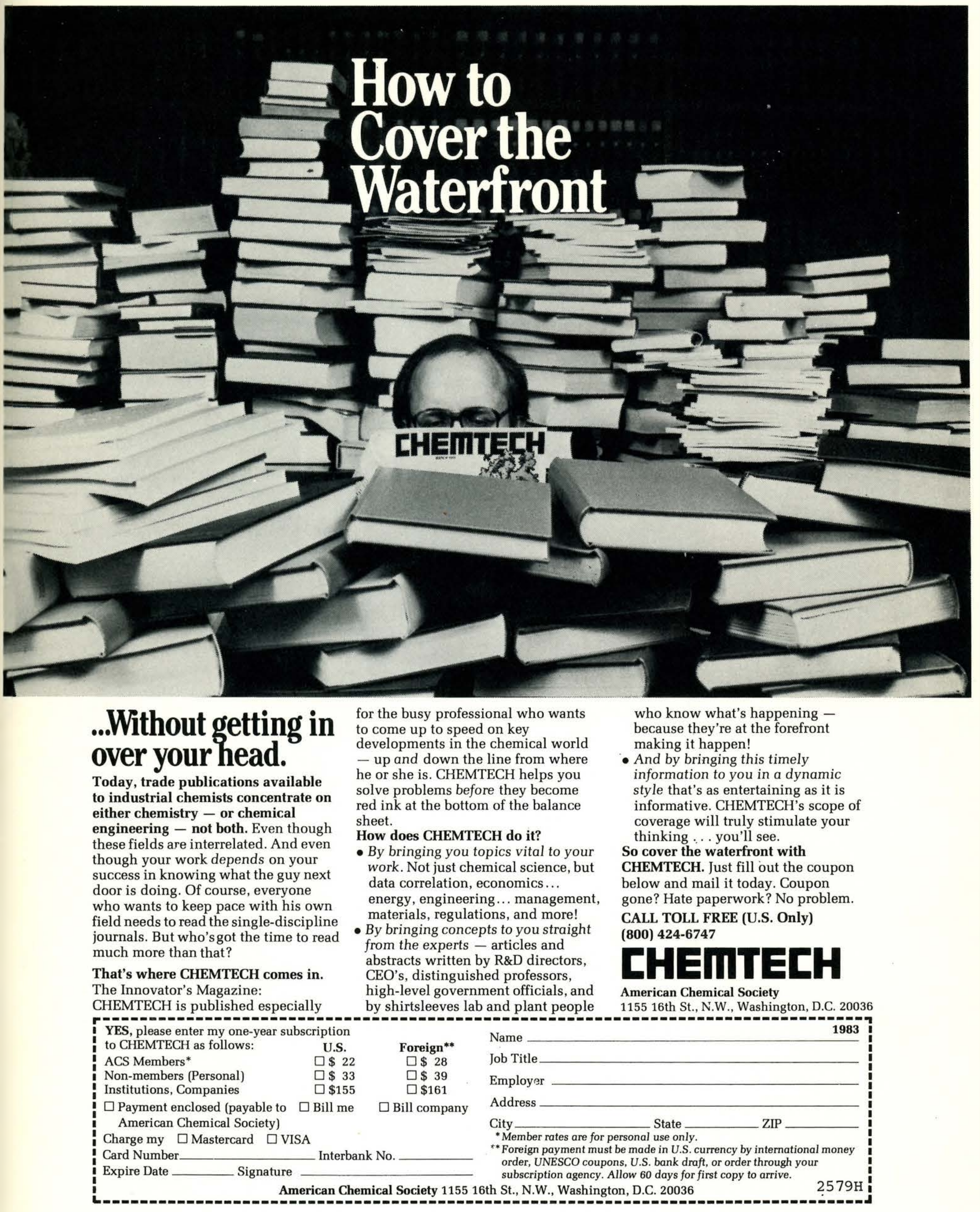




\section{Government Programs and Projects Directory}

... A Guide to National Programs and Projects Administration by the Executive Departments and Independent Agencies of the U.S. Government. 1st ed. published in 3 softbound parts. Edited by Anthony T. Kruzas and Kay Gill. About 500pp. Cumulative name and keyword index. Gale, 1983-84. ISBN 0-8103-0422-8. Sub., $\$ 85.00$. (SO) (Part 1 in print)

Meeting a long felt need, this new directory provides facts and figures on 1,200 programs implemented, managed, and supported by executive departments of the Federal Government.

\section{Training and Development Organizations Directory}

... A Reference Work Describing Firms, Institutes, and Other Agencies Offering Training, Professional, and Personal Development Programs for Business, Industry, and Government. 3rd ed. Edited by Paul Wasserman and Janice McLean. 1,198pp. Indexes. Gale, 1983. ISBN 0-8103-0432-5. \$200.00. (SO) New Training Organizations. Inter-ed. supp., $\$ 125.00$. (SO)

With the growing recognition of the benefits of management training, numerous organizations devoted to training and development have become established. This key sourcebook gives details and extensive profiles of the activities and specialties of nearly 2,000 companies, institutes, and special consulting groups in the field.

\section{Research Centers Directory}

... A Guide to University-Related and Other Nonprofit Research Organizations Established on a Permanent Basis and Carrying on Continuing Research Programs in Agriculture, Business, Conservation, Education, Engineering and Technology, Government, Law, Life Sciences,
Mathematics, Area Studies, Physical and Earth Sciences, Social Sciences, and Humanities. 8th ed. Edited by Mary Michelle Watkins and James A. Ruffner. $1,088 \mathrm{pp}$. Indexes. Gale, 1983. ISBN 08103-0458-9. \$200.00. (SO) New Research Centers. Inter-ed. supp., $\$ 180.00$. (SO)

Completely revised and updated, the new edition contains over 6,600 unduplicated entries on centers in the U.S. and Canada.

\section{Biography Almanac}

... A Comprehensive Reference Guide to More than 23,000 Famous and Infamous Newsmakers from Biblical Times to the Present as Found in Over 300 Readily Available Biographical Sources. 2nd ed. Edited by Susan L. Stetler. Gale, 1983. Vol. 1, Biographies. 1,346pp. ISBN 0-8103-1632-3. \$48.00. (SO) Vol. 2, Indexes. 1,026pp. ISBN 08103-1633-1. \$48.00. (SO) $\$ 85.00 /$ set. Biography Almanac-Supplement, $\$ 35.00$. (SO)

The new edition adds an index volume that arranges the 23,000 entries chronologically by year, chronologically by date, and geographically, using places and dates of birth and death. Volume 1 is arranged alphabetically and provides brief biographical data together with citations to biographical sketches appearing in over 300 widely held sources.

(SO) These titles are available at Gale's 5\% Standing Order discount. Deduct 5\% if you send check with order. Customers outside the U.S. and Canada add $10 \%$.

\section{GALE Research Co. Book Tower • Detroit, MI 48226}

To order by phone: 1-800-521-0707 tollfree. In Canada, Michigan, Alaska, and Hawaii: 1-313-961-2242. 